\title{
RECYCLING POTENTIAL OF TEXTILE SOLID WASTE
}

\author{
MOHAMMAD FAHIM HASAN, NOWRIN MOW, MOHAMMAD RAKIBUL ALAM, \\ SARDAR MOHAMMAD ABIR HASAN \& ROWSHAN MAMTAZ \\ Bangladesh University of Engineering and Technology (BUET), Bangladesh
}

\begin{abstract}
With increasing production of textile products, textile industries (TIs) are generating a considerable amount of liquid and solid wastes which bring in many adverse impacts on the environment such as landfill occupation, contamination of air, soil, surface water, and groundwater. In Bangladesh, while prioritizing the disposal and management of textile liquid wastes, the necessity of management of textile solid wastes (TSWs) are often neglected. TSW is generated in a considerable amount but no proper management or disposal system is followed by the industries. An attempt has been made in this study to find a sustainable disposal option for TSW. The experiments were conducted throughout 2016. This research is concerned with a particular type of solid waste, very dusty in composition, generated from slitting, brushing and sueding machine in the dyeing unit of the composite TI. Using this particular type of TSW, papermaking was attempted following manual procedures. TSW at ten different ratios were added to scrap abandoned paper mixture (paper: waste $=1: 0.25,1: 0.5$, $1: 0.75,1: 1,1: 1.5,1: 2,1: 2.25,1: 2.5,1: 2.75,1: 3$, etc.) to produce papers. A pulp consistency test and different tests on produced paper e.g. basis weight, bulk, and density, book bulk, thickness, hygroexpansivity, formation, moisture, and finish were conducted according to Technical Association of the Pulp and Paper Industry (TAPPI) methods and ISO standards were followed to determine the quality of pulp and type of papers. The result was promising and showed a high potential for the use of TSW in the papermaking industry. Following the test results found in this research it can be said that the solid waste can be efficiently used mainly for making blotting paper, tissue, official or business paper, and paperboard, etc. Further research with a large amount of sample from different industries along with high-end equipment may disclose more information about the recycling extent of this TSW.
\end{abstract}

Keywords: contamination, papermaking, recycling, sustainable alternative, textile solid waste.

\section{INTRODUCTION}

The textile industries are one of the most expanding and profitable sectors in the economy of Bangladesh. Being one of the leading exporters in this sector, these industries are the source of $78 \%$ of the country's export earnings and contribute to $5 \%$ of country's national income [1].

Despite its significant contribution to the economy of Bangladesh, textile industries have been posing a significant threat to the environment, especially to the water source and air quality. It is a matter of relief that authorities are trying to identify units of generation of wastewater and sludge and to establish and enforce environmental acts and laws for controlling the industry effluents. At present many industries have operation units like ETP for wastewater and sludge treatment, along with other processes to reduce the generation of liquid waste.

However, the alarming fact is that priority has not been given to the management of huge volume of textile solid waste produced. In the textile industry, the generation of textile solid waste varies widely in amount and type depending on the type of industry and its production capacity. Industries regard this solid waste as non-recyclable and dump it in landfill and water bodies. A significant amount of these wastes consists of very fine particulates and causes air and water pollution mixing with air and water respectively. With the landfill sites becoming more scarce and environmental regulations being more stringent, 
opportunities have to be found out for disposal of textile solid waste in a harmless and effective manner.

The objective of this study is to suggest an alternative option to the open disposal of textile solid waste and saving the environment from adverse effects. Therefore, finding recycling opportunity for a specific type of textile solid waste has been the prime concern of this research. Textile solid waste generated from slitting, brushing and sueding machine in dyeing unit of a composite textile industry has been regarded as the waste material for which recycling opportunities have been explored.

An attempt was made to recycle this TSW in the production of paper. Paper pulp generally consists of various types of materials like scrap paper, wood dust, and bamboo fibers. The inclusion of the textile solid waste may prove economically effective. The papers have been made following a manual procedure.

\section{SITE LOCATION AND SAMPLE COLLECTION}

For the study, the dry solid waste sample was collected from Islam Garments Ltd., a composite textile industry located in Gazipur, outskirts of the capital Dhaka of Bangladesh. The geographic coordinate of the industry is $23^{\circ} 59^{\prime} 21.0^{\prime \prime} \mathrm{N}$ and $90^{\circ} 19^{\prime} 08.5^{\prime \prime} \mathrm{E}$.

Solid waste samples were collected at the point of generation, from brushing and sueding machines, and also from the backside of the factory where this waste was dumped in open atmosphere and near the water body. The waste generation location is shown in Fig. 1(a), (b). Fig. 2 shows some TSW sample and Fig. 3 shows the present disposal practice which is the sample collection location.

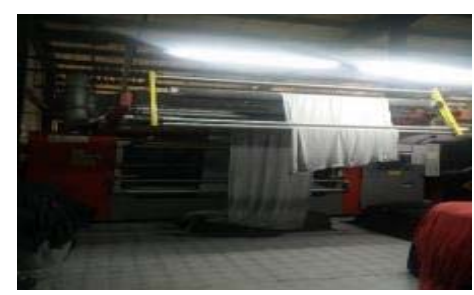

(a)

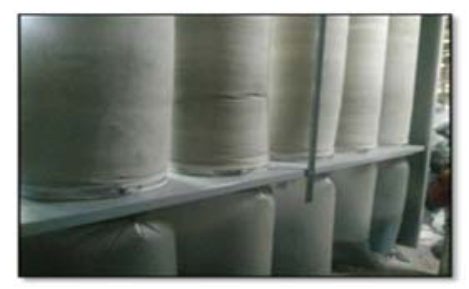

(b)

Figure 1: TSW generation in sueding machine. (a) Sueding machine; (b) TSW collector of sueding machine.

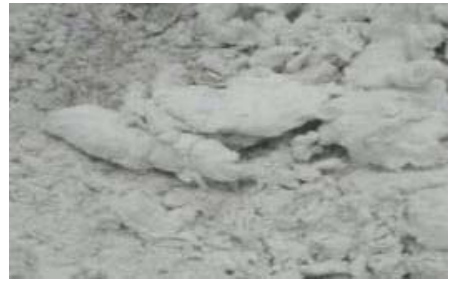

Figure 2: TSW sample.

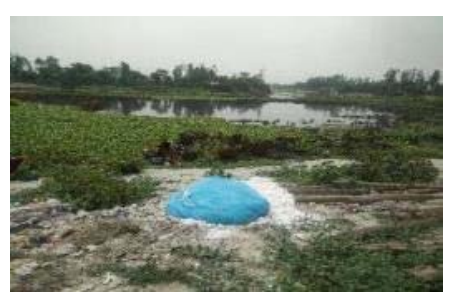

Figure 3: Present disposal practice. 


\section{METHODOLOGY}

\subsection{Materials used for papermaking}

As a recycling option, papermaking was chosen with the solid waste generated in slitting and sueding machine. The research was conducted throughout 2016 and was submitted as a thesis to Department of Civil Engineering, BUET in February 2017. A simple manual procedure was followed with the facilities of the Environmental Engineering Laboratory of Bangladesh University of Engineering and Technology (BUET). The list of materials used are given below and shown in Fig. 4.

- $\quad$ Dry solid waste sample: sample was collected directly from industry;

- Thrown away papers: newspaper, used A4 size paper, poster etc.;

- Glue: very small amount of paper glue was used;

- Water: amount needed for TSW sample workability.

\subsection{Ratio of waste materials}

A total of ten sample papers were made for different ratios of TSW and thrown away papers. Table 1 shows those ratios of textile solid waste in the produced papers.

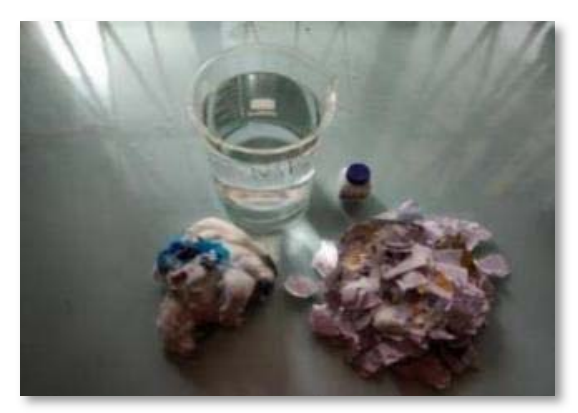

Figure 4: Materials used in paper making process.

Table 1: Ratios of waste paper to TSW in different samples.

\begin{tabular}{|c|c|}
\hline Serial No. & Ratio of waste paper : TSW \\
\hline 1 & $1: 0.25$ \\
\hline 2 & $1: 0.50$ \\
\hline 3 & $1: 0.75$ \\
\hline 4 & $1: 1.00$ \\
\hline 5 & $1: 1.50$ \\
\hline 6 & $1: 2.00$ \\
\hline 7 & $1: 2.25$ \\
\hline 8 & $1: 2.50$ \\
\hline 9 & $1: 2.75$ \\
\hline 10 & $1: 3.00$ \\
\hline
\end{tabular}




\subsection{Procedure}

The paper samples were made in a totally manual process without incorporation of any commercial instrument for papermaking. The workflow of the process is described below.

1) Soaking of TSW in water for about 1 hour.

2) Blending of wet TSW (15-20 minutes) with scrap paper and glue $(0.5 \mathrm{ml})$ by an electronic blending machine.

3) Pouring the blended mush into a bowl filled with water.

4) Using a screen ( $0.6 \mathrm{~mm}$ opening) to collect the mush evenly (the screen was set at the bottom of the bowl and materials in the bowl were gently steered to ensure that the screen would collect mush evenly).

5) Placing the screen with mush upside down and pressing with a water absorbent fabric (gently pressed to remove water from the mush as much as possible, to decrease the drying time).

6) Removing the screen.

7) Drying the wet paper in open air condition for 48 hours and after that in an oven at $105^{\circ} \mathrm{C}$ for 1 hour.

8) Resizing the finished paper in rectangular shape.

The manual process conducted in this study was a simplified process as there was lack of opportunities to conduct mechanical process. Before invention of mechanical processes, manual processes were used widely to produce paper and still in some cases these manual processes are followed for producing paper like fancy papers. Being a manual process, the thickness and size of the produced papers could not be maintained uniformly for different ratio of TSW. It would be more reliable and efficient if mechanical processes chould have been incorporated. But in this manual process which papers were produced, apparently satisfied the properties of mechanically produced papers. Fig. 5 shows different steps that are applied in the manual process to produce papers using TSW.

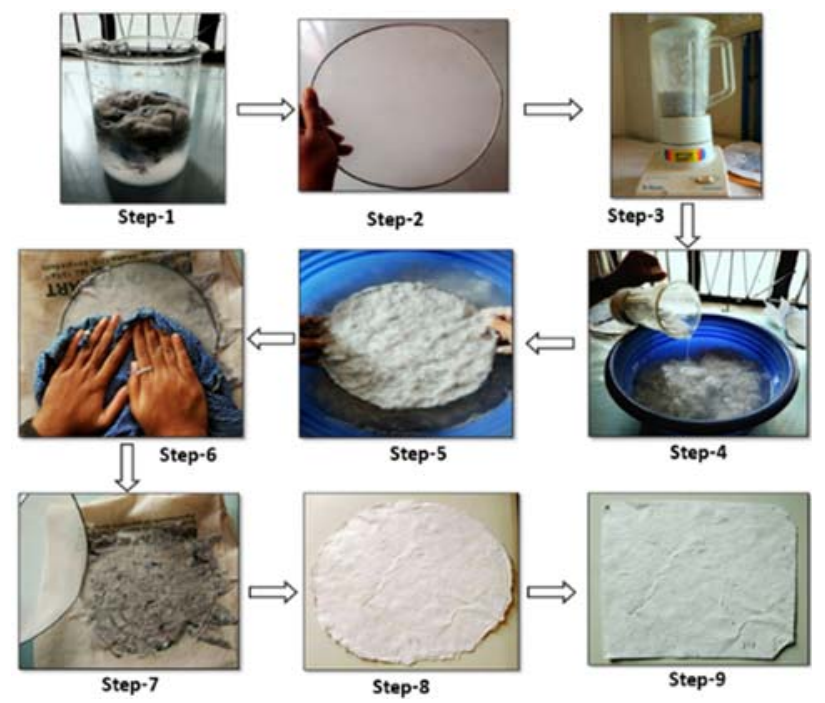

Figure 5: Workflow of paper making process. 
Following the procedure shown in Fig. 5, a series of finished paper samples (Fig. 6) were produced with varying ratios of scrap paper to TSW sample. The TSW samples mostly were white in color which resulted in white papers except from the blue paper made from blue TSW sample.

\subsection{Testing pulp and paper}

Several tests were conducted to determine properties of the material and produced papers. The tests were performed by following the methodology of Technical Association of the Pulp and Paper Industry (TAPPI). However, for simplicity, some testing equipment were replaced by simpler ones. The tests performed are mentioned below along with followed TAPPI code.

(a) Analysis of Pulp Consistency: TAPPI T240 om-93.

(b) Basis Weight or Grammage: TAPPI T 410 om-08.

(c) Bulk and Density: TAPPI T $220 \mathrm{sp}-01$.

(d) Book Bulk: TAPPI T $500 \mathrm{~cm}-07$.

(e) Caliper or Thickness: TAPPI T 411 om-97.

(f) Hygroexpansivity.

(g) Formation (subjective evaluation).

(h) Moisture Absorption: TAPPI T 550 om-93.

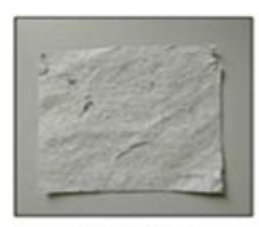

(a) 1:0.25 ratio

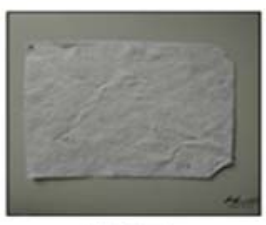

(d) 1:1 ratio

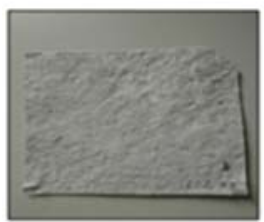

(e) 1:2.25 ratio

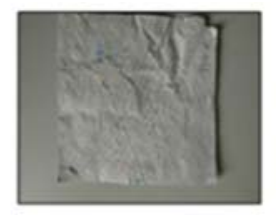

(b) 1:0.5 ratio

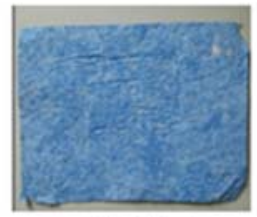

(e) $1: 1.5$ ratio

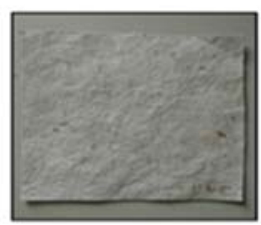

(h) 1:2.5 ratio

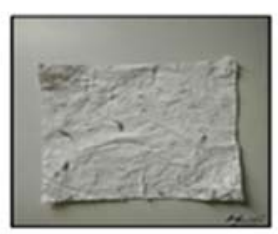

(6) 1:3 ratio

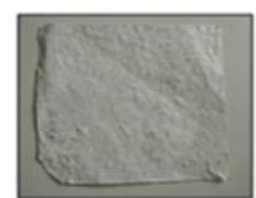

(c) 1:0.75 ratio

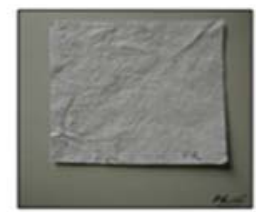

(f) $1: 2$ ratio

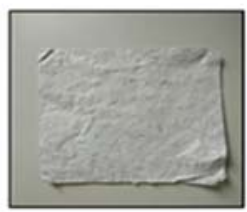

(i) 1:2.75 ratio

Figure 6: Papers made at different scrap paper: TSW ratios. 


\section{TEST RESULTS AND ANALYSIS}

\subsection{Analysis of pulp consistency}

The obtained results of pulp consistency test are shown in Table 2. According to TAPPI, if the percent consistency of sample pulp is less than $5 \%$, the sample is considered to be low consistent which is less desirable. Lower consistency means there is excess dilution water which ends up eventually as effluent. If more percentage of waste is used, more water will be needed in the papermaking process. All the samples used in the experiment had percent consistency well below than $5 \%$ and considered to be low consistent. It is due to manual mixing procedure of the pulp. A better mixing process might have improved the results [2].

\subsection{Basis weight or grammage of produced paper}

Basis weight is an important physical property of paper, which indicates the quality of the paper. Fluctuation in basis weight for a specific type of paper indicates deterioration in its quality. Fig. 7 is a graph of basis weight vs. \% of waste.

Table 2: Pulp consistency test results of pulp sample.

\begin{tabular}{|c|c|c|}
\hline $\begin{array}{c}\text { Waste ratio in sample } \\
\text { (paper : waste) }\end{array}$ & $\begin{array}{c}\text { Net weight of the original } \\
\text { specimen in beaker }(\mathrm{gm})\end{array}$ & $\begin{array}{c}\text { Percent consistency } \\
\mathrm{C}(\%)\end{array}$ \\
\hline $1: 0.25$ & 568.96 & 0.36 \\
\hline $1: 0.5$ & 577.09 & 0.13 \\
\hline $1: 0.75$ & 587.2 & 0.45 \\
\hline $1: 1$ & 576.65 & 0.5 \\
\hline $1: 2$ & 598.91 & 0.23 \\
\hline $1: 2.25$ & 561.02 & 0.43 \\
\hline $1: 2.5$ & 575.09 & 0.63 \\
\hline $1: 2.75$ & 579.3 & 0.09 \\
\hline $1: 3$ & 604.1 & 0.70 \\
\hline
\end{tabular}

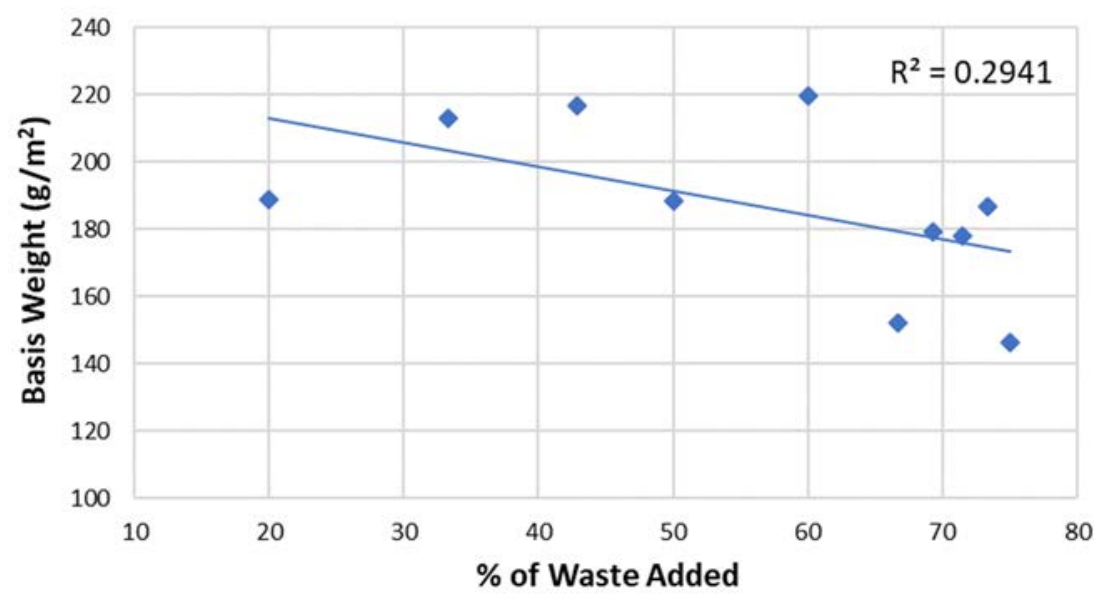

Figure 7: Basis weight vs. \% of waste addition graph. 
The basis weight of all prepared samples are between $120 \mathrm{~g} / \mathrm{m}^{2}$ to $300 \mathrm{~g} / \mathrm{m}^{2}$ which matched with the paper grade section of paperboard according to TAPPI. From the graph of basis weight vs. $\%$ of waste (Fig. 7) it has been observed that with the increased addition of waste, the basis weight of paper started decreasing which is desirable for papermaker [3].

\subsection{Bulk and density of paper}

The graph of bulk vs. \% of waste (Fig. 8) shows that bulk increases as more waste is added in the pulp. High bulk is desirable in absorbent papers while the lower bulk is preferred for printing papers particularly dictionary paper etc. [4]. The result shows that using less than $10 \%$ of waste, paper can be produced of any variety. With more $\%$ of waste more absorbent papers can be produced.

Density is reciprocal to bulk. With the increase in \% of waste density decreases which has been presented in Fig. 9.

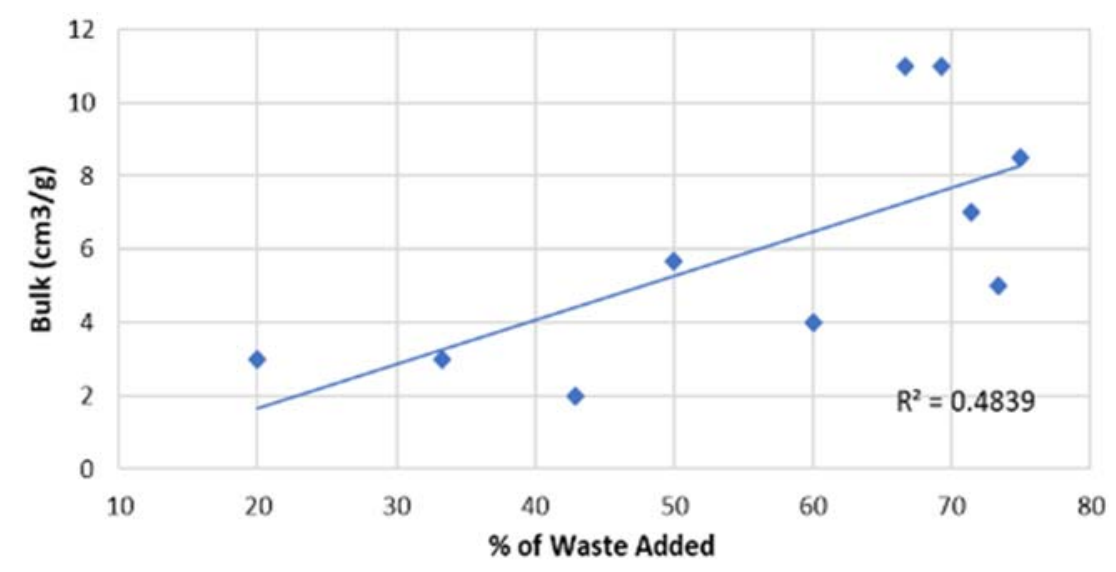

Figure 8: Bulk $\left(\mathrm{cm}^{3} / \mathrm{g}\right)$ vs. $\%$ of waste added graph.

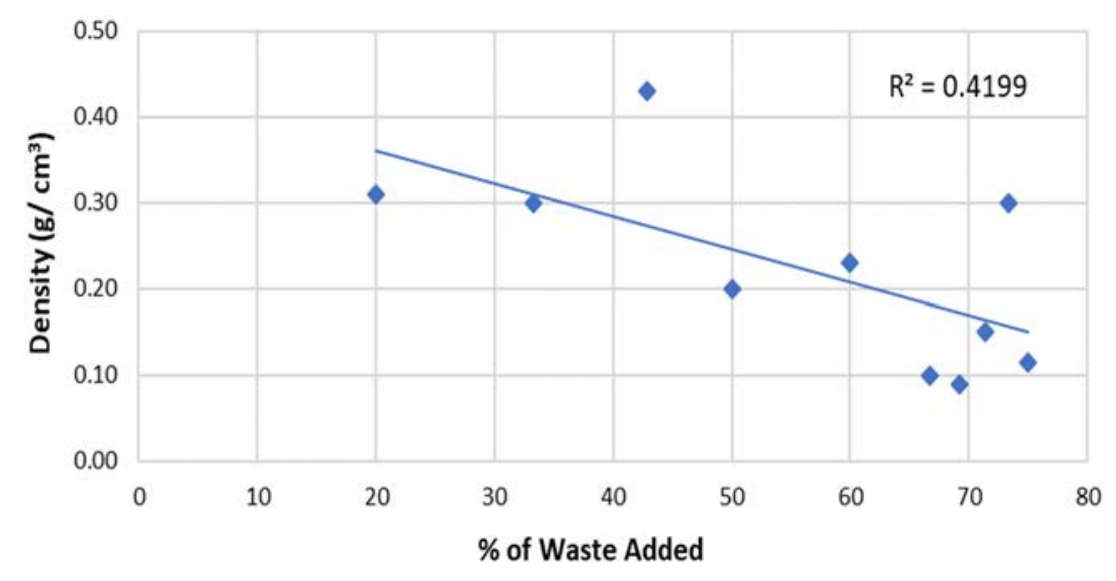

Figure 9: Density $\left(\mathrm{g} / \mathrm{cm}^{3}\right)$ vs. $\%$ of waste added graph. 


\subsection{Thickness of produced paper}

For a given basis weight, thickness determines how dense paper is. Due to equipment constraints this property has been measured by slide calipers instead of a micrometer. It is observed that thickness of maximum paper samples is greater than $540 \mu \mathrm{m}$. According to TAPPI, those can be used as blotting papers [5].

A graph of thickness vs. \% of waste added (Fig. 10) shows that thickness increases with addition of waste. Thickness is important for cards, printing papers, condenser paper, saturating papers etc. According to ISO standard, the thickness of blotting paper ranges from $540 \mu \mathrm{m}$ to $590 \mu \mathrm{m}$ which is the thickness ranges found in this research. As the manual process is applied, the thickness varies in large ranges and all are greater than $540 \mu \mathrm{m}$. If a mechanical process could be applied, the result could be more precise.

\subsection{Hygroexpansivity}

Hygroexpansivity is the percentage elongation or shrinkage due to its surrounding moisture content [6]. All papers expand with increased moisture content and contract with decreased moisture content, but the rate and extent of changes vary with different papers. In Fig. 11, a graph has been plotted between percent of elongation vs. \% of waste added.

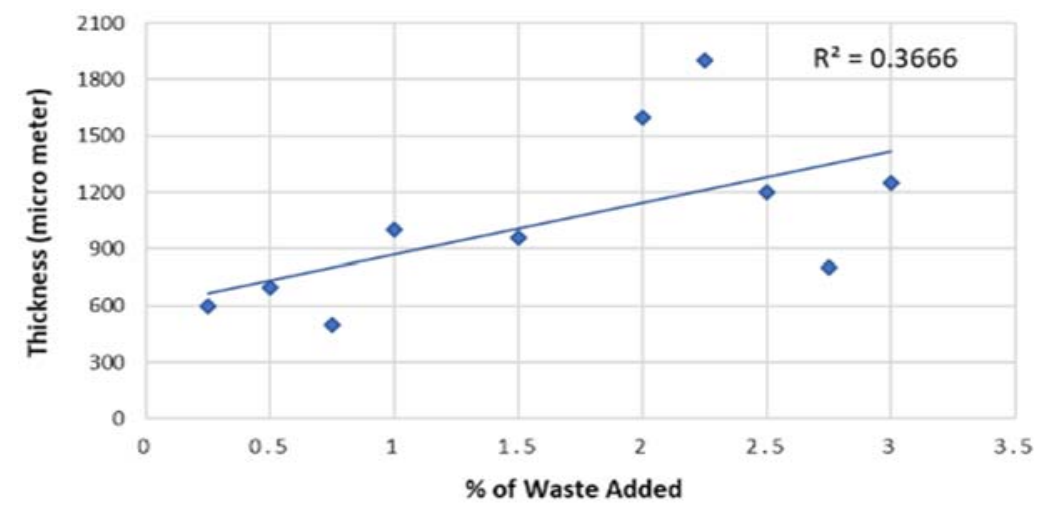

Figure 10: Thickness $(\mu \mathrm{m})$ vs. \% of waste added graph.

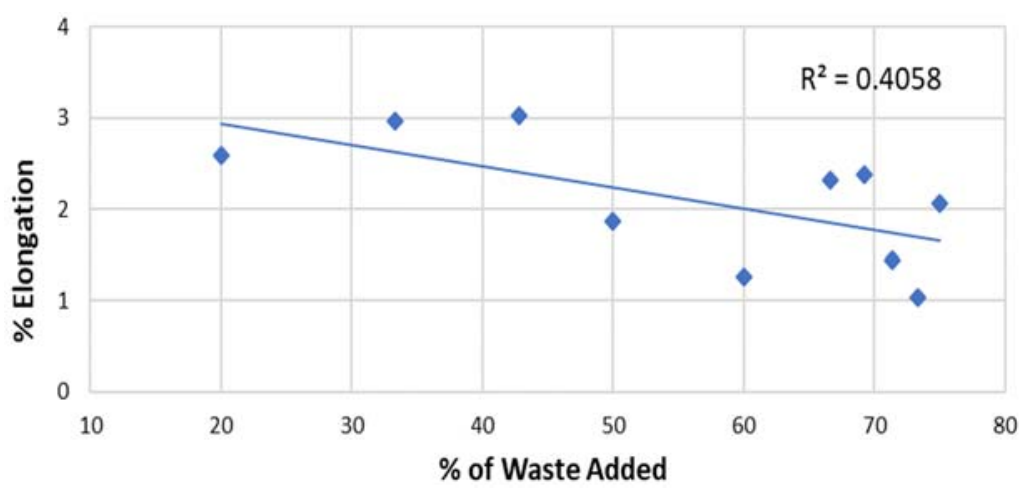

Figure 11: Percentage of elongation vs. percentage of waste added graph. 
The plot shows that the $\%$ of elongation decreases with the increase of waste addition. It also indicates that with the increase of waste addition the rate and extent of changes decreased.

\subsection{Formation}

Formation is an indicator of how uniformly the fibers and fillers are distributed in the sheet. When holding the paper up to a light source, a well-formed sheet appears uniform while a poorly formed sheet has clumps of fibers giving a cloudy look. With the increased amount of added waste, the formation changes from uniform to cloudy look which is shown in Fig. 12. It has been observed that with the increase in the percentage of wastes, the hardness of paper decreases. The papers with the maximum percentage of wastes are soft in nature. Therefore, hard papers containing the low percentage of textile solid wastes can be suitable for packaging paper while papers with the higher percentage of waste suitable for tissue or blotting paper [7].

Several paper samples were torn to observe the bonding between materials. While attempting to tear the papers with hands (applying regular force needed to tear a paper), they have exhibited good resistance. The samples contain fibrous materials from the textile solid wastes which are visible in torn paper pieces, rendering bonding and strength to paper.

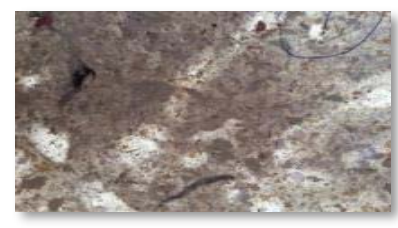

(a) $20 \%$ waste added

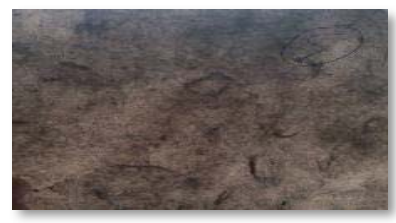

(d) $50 \%$ waste added

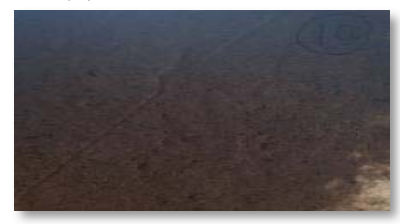

(g) $69.23 \%$ waste added

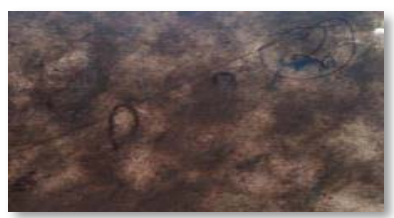

(b) $33.33 \%$ waste added

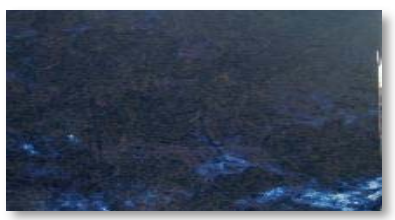

(e) $60 \%$ waste added

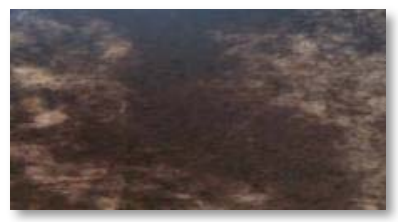

(h) $71.43 \%$ waste added

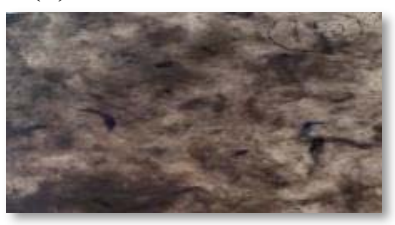

(j) $75 \%$ waste added

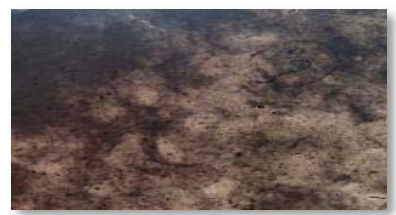

(c) $42.86 \%$ waste added

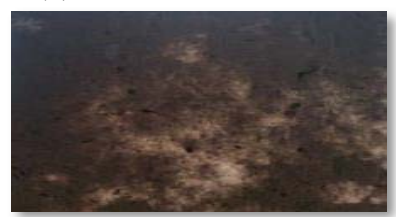

(f) $66.67 \%$ waste added

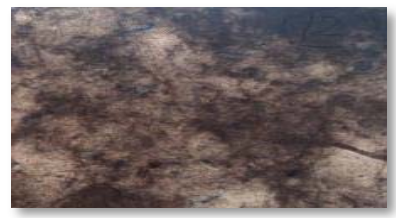

(i) $73.33 \%$ waste added

Figure 12: Formation of paper with the different amounts of added waste. 
Using the same mix ratio of scrap paper to solid waste, variation in quality of papers has been observed. The difference in quality is due to lack of process control while making paper in manual method. The following Fig. 13 shows torn pieces of paper containing fibrous materials.

\subsection{Moisture absorption of paper at normal temperature}

Moisture content (MC) has been calculated from the difference of weights of the samples in normal and oven dry condition. MC of all the samples is between 3\% to $7 \%$ and it has been observed that the moisture content decreases with the increase of the waste proportion in the samples (Fig. 14). Paper with MC $2-7 \%$ can be classified as tissue paper, with MC $4-4.5 \%$ can be classified as business paper and with MC 6-7\% can be classified as office paper [8].

\subsection{Classification of produced paper based on usability}

Considering the above mentioned test results (Sections 4.2, 4.5 and 4.8), the produced papers has been classified for different use and shown in Table 3.

\section{CONCLUSIONS}

Following the test results found in this research it can be said that the solid waste can be efficiently used in papermaking with a combination of other materials like scraped paper in pulp. It is difficult to establish correlation between properties of papers with the tests

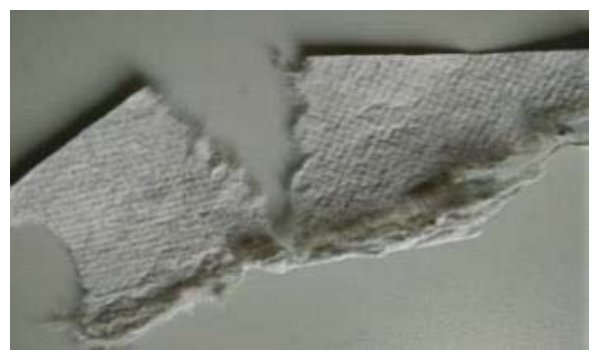

Figure 13: Fibrous formation in torn paper pieces.

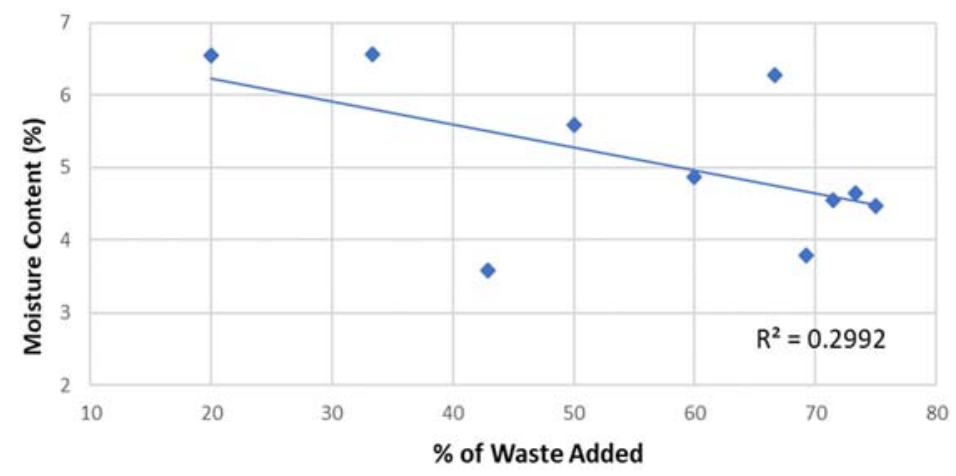

Figure 14: Moisture content (\%) vs. \% of waste added graph. 
Table 3: Classification of paper samples.

\begin{tabular}{|c|c|c|c|c|c|}
\hline \multirow{2}{*}{ Serial no. } & \multirow{2}{*}{$\begin{array}{c}\text { Scrap paper : } \\
\text { waste ratio } \\
\end{array}$} & \multicolumn{1}{|c|}{ Classification based on usage } \\
\cline { 3 - 6 } & $1: \mathrm{X})$ & Basis weight & Thickness & \multicolumn{2}{|c|}{ Moisture content } \\
\hline 1 & 0.25 & Paperboard & Blotting paper & Tissue & Printing paper \\
\hline 2 & 0.50 & Paperboard & Blotting paper & Tissue & Printing paper \\
\hline 3 & 0.75 & Paperboard & Blotting paper & Tissue & \\
\hline 4 & 1.00 & Paperboard & Blotting paper & Tissue & \\
\hline 5 & 1.50 & Paperboard & Blotting paper & Tissue & \\
\hline 6 & 2.00 & Paperboard & Blotting paper & Tissue & Printing paper \\
\hline 7 & 2.25 & Paperboard & Blotting paper & Tissue & \\
\hline 8 & 2.50 & Paperboard & Blotting paper & Tissue & Office paper \\
\hline 9 & 2.75 & Paperboard & Blotting paper & Tissue & \\
\hline 10 & 3.00 & Paperboard & Blotting paper & Tissue & Office paper \\
\hline
\end{tabular}

performed due to lack of process control. But the test results show that the sample can be used in making blotting paper, tissue, official or business paper and paperboard. Further research with a large amount of sample from different industries along with high end equipment may disclose more information about the recycling extent of this TSW.

Bangladesh is a leading apparel exporter in the world alongside India, China, and Vietnam. This sector contributes to the country's $80 \%$ of total export and holds the $2^{\text {nd }}$ position in clothing export throughout the world [9]. This indicates the volume of resource involvement and amount of waste generation from these industries. In 2025, the generation of solid waste is estimated to reach 43,000 tons/year, with $60-72 \%$ of the waste untreated [10]. The current practice of open disposal and landfilling of the TSW has ill impacts on the environment such as air and water pollution. The research work has demonstrated a feasible way of using the specific type of textile industry's solid waste as an ingredient of paper which can be a sustainable alternative to the present disposal practice. As this particular type of dusty cotton-like solid waste is generated in almost all textiles industries in Bangladesh, it comprises a large volume and can be beneficial economically if reused properly. The economic gains of this alternative option to reuse TSW in papermaking couldn't be assessed in this study as it involves a large sample size and industry involvement. At an early age, before paper production in industries, the most common fiber source was recycled fibers from used textiles, called rags. The rags were from hemp, linen, and cotton. The textile solid waste which is used in this research is $90 \%$ of cotton and $10 \%$ of other synthetic fibers (information collected from the industry). Therefore, textile fibers have a history to be used in papermaking and this justifies the involvement of TSW of this study to be used in paper industry.

\section{ACKNOWLEDGMENTS}

The authors are grateful to the Environmental Engineering Division of Department of Civil Engineering, Bangladesh University of Engineering and Technology for providing all the facilities. The authors are also thankful to Islam Garments Ltd. for providing the opportunity to visit the industry and collect the textile solid waste samples. 


\section{REFERENCES}

[1] Ahmed, T. \& Tareq, S.M., Textile industries in Bangladesh: A rising environmental degradation down the drains, Bangladesh Textile Today, pp. 1-2, 2008.

[2] Consistency (concentration) of pulp suspensions. http://grayhall.co.uk/Beloit Research/tappi/t240.pdf. Accessed on: 5 Dec. 2017.

[3] TAPPI T 410 OM-08, Grammage of paper and paperboard (weight per unit area). https://infostore.saiglobal.com/en-au/Standards/TAPPI-T-410-om-08-1079196/. Accessed on: 5 Dec. 2017.

[4] Properties of paper, physical properties, pulp and paper resources and information site. www.paperonweb.com/paperpro.htm. Accessed on: 5 Dec. 2017.

[5] Thickness (caliper) of paper, paperboard and combined, board. http://grayhall.co.uk/BeloitResearch/tappi/t411.pdf. Accessed on: 5 Dec. 2017.

[6] Properties of paper, physical properties: hygroexpansivity, pulp and paper resources and information site. www.paperonweb.com/paperpro.htm. Accessed on: 5 Dec. 2017.

[7] Properties of paper, physical properties, pulp and paper resources and information site. www.paperonweb.com/paperpro.htm. Accessed on: 5 Dec. 2017.

[8] Determination of equilibrium moisture in pulp, paper, and paperboard for chemical analysis. http://balibago.org/Files/Tappi/DOCS/T550.PDF. Accessed on: 5 Dec. 2017.

[9] Masum, M. \& Inaba, K., A comparative input-output analysis of the textile-clothing industry in Bangladesh and some Asian countries. Proceedings of the 10th RICA Conference, Bangkok, Thailand, p. 103, 2015.

[10] Kadolph, S.J., Quality Assurance for Textiles and Apparel, ISBN: 156367-144-1, GST R: 133004424, pp. 65-89, 2012. 